\section{En barnelege erindrer}

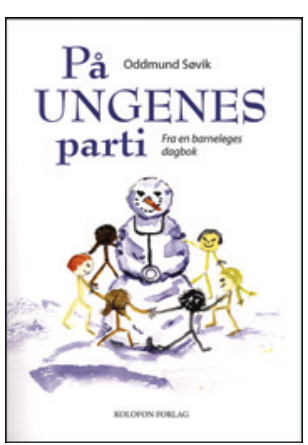

Oddmund Søvik

På ungenes parti

Fra en barneleges dagbok. $271 \mathrm{~s}$, ill. Oslo:

Kolofon Forlag, 2015. Pris NOK 250

ISBN 978-82-300-1259-8

Oddmund Søvik, mangeårig professor og overlege ved Barneklinikken, Haukeland universitetssykehus, er en av norsk barnemedisins nestorer. På ungenes parti består av ni kapitler, med titler som beveger seg fra Viten, vett og vitenskap til Barn i krig. Bare korte deler er faktisk fra hans dagbok. Når eldre kolleger skriver om sine liv og sine fag, gir de oss materiale til å forstå både fagenes utvikling og enkeltmenneskers reise gjennom et landskap som har endret seg dramatisk. Både med den bakgrunnen, og fordi jeg har lest litt av det Oddmund Søvik tidligere har skrevet og gitt ut, åpnet jeg boken med positiv forventning.

Kapitlene spenner over et svært vidt felt, og jeg spør meg som leser om hvilken målgruppe forfatteren henvender seg til. Så vidt jeg kan se, forteller ikke Søvik oss dette, og etter å ha lest boken er jeg fortsatt ikke sikker på hvem han egentlig ønsker å få i tale. Jeg tror ikke at han henvender seg spesielt til kolleger, fordi han omtaler og forklarer medisinske tilstander og begreper på en måte som ikke synes nødvendig for disse. Jeg antar derfor at han har en større og mer generell målgruppe i tankene. Om han faktisk treffer disse, er jeg usikker på.

Boken er gitt ut på Kolofon Forlag. På forlagets hjemmesider kan man bl.a. lese: «I en lang demokratisk tradisjon står Kolofon som garantist for at alle som har noe fornuftig å melde skal kunne komme til orde, også i bokform.» Man får inntrykk av prosessen fra mottakelse av manus til faktisk utgivelse ikke innebærer noen redaksjonelle bidrag fra forlagets side. Jeg tror denne teksten nettopp kunne profittert på profesjonell hjelp til redigering. Da kunne man bidratt til en synligere sammenheng i stoffet og ryddet unna gjentakelser og andre forhold som trekker ned inntrykket. Således tenker jeg at dagboksnotatene fra Kongo i 1961, selv om de på mange måter er dramatisk og spennende lesning, burde vært redigert. Som leser ønsket jeg meg her at Søvik, med den ballasten han har i dag, hadde «trådt til side» og problematisert noen av de refleksjonene han gjorde seg som 28-årig lege.

Søvik har mange viktige tanker å meddele, og jeg tror at både yngre og eldre kolleger vil finne deler interessant. Det er leit at de mulighetene som utvilsomt ligger i boken, ikke er forløst slik den nå foreligger.

\section{Thor Willy Ruud Hansen}

Overlege, Nyfødtavdelingen

Kvinne- og barneklinikken

Oslo universitetssykehus

\section{Viktig og bra om barn og seksualitet}

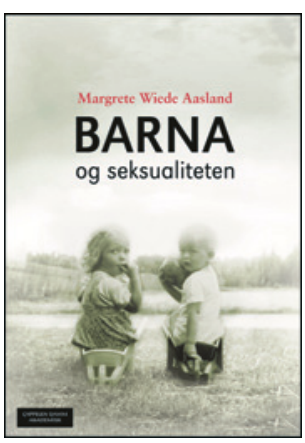

Margrete Wiede Aasland

Barna og seksualiteten

119 s, ill. Oslo: Cappelen Damm Akademisk, 2015. Pris NOK 249

ISBN 978-82-02-41847-2

Denne lille boken med det tiltalende omslagsbildet har en nokså stor ambisjon. Forfatteren ønsker nemlig å gi alle som arbeider med barn, utdanner seg til å arbeide med barn, har omsorg for barn eller selv har barn, innsyn i hvordan den delen av barnas verden som handler om seksualitet og utforskning av egen og andres kropper, vanligvis foregår. Forfatteren vil også vise voksne hvordan de kan møte barna og deres kroppslige og seksuelle utforskning på en god måte.

Det er altså et følelsesladet og tabubelagt tema som forfatteren tar opp. Hun har selv arbeidet innen feltet siden 1980-årene, både som terapeut og underviser. Boken er hovedsakelig basert nettopp på dette erfaringsgrunnlaget. De mange eksemplene og korte historiene engasjerer og skaper en troverdig nærhet til stoffet. Underveis er det satt inn referanser og kommentarer fra psykologspesialist Thore Langfeldt. Tekstbokser, korte kapitteloppsummeringer og beskrivende tegninger gir utfyllende «hvilesteder» underveis.

Boka er bygd opp i to deler. Den første delen viser barns seksuelle utvikling og hvordan seksualiteten kommer til uttrykk på ulike utviklingstrinn. I den andre delen forklarer forfatteren hvordan voksne kan forstå, møte og snakke med barna om seksualitet og deres kroppslige utforskning og lek.

Et viktig poeng hos forfatteren er at mindre barn i liten grad har noen opplevelse eller egen forståelse av seksualitet og hva seksualitet er. Leken og utforskningen de driver med, er naturlig for barna. Det er vi voksne som oppfatter og tolker disse aktivitetene som seksuelle. Våre reaksjoner, og måten vi møter barna på, er avgjørende og bidrar til å forme barnets selvbilde, synet på sin egen kropp og seksualitet - og i hvilken grad barnet utvikler seg til et sunt, selvstendig og trygt menneske.

Et annet sentralt poeng for forfatteren er grensesetting. Barnet må lære å sette grenser for seg selv og sin egen kropp. Det må også lære å respektere andres grenser. Ingen kan tvinges til noe de ikke vil.

Dette en tankevekkende og viktig bok. Den gir kunnskap, men utfordrer og setter ord på de vanskelige følelsene. Teksten vil være et nyttig redskap så vel for studenter som foreldre og alle som arbeider med barn. Ikke minst vil leger og andre helsearbeidere få innspill til å tilnærme seg barn og deres foreldre om et vanskelig tema de aller fleste av oss ikke er trent til å snakke om.

\section{Haakon Aars}

Spesialist i psykiatri, Institutt for klinisk sexologi og terapi Oslo 